\title{
Italy to quit European biology lab in protest over staffing policy
}

Bonn. Italy has shocked the world of European science by announcing its intention to resign from the European Molecular Biology Laboratory (EMBL), based at Heidelberg in Germany, claiming that it does not get a fair return on its annual subscription to the laboratory.

The decision was announced on 28 December, and will, unless reversed, come into effect at the end of this year. It has surprised many EMBL council members, who had previously been optimistic that Italy's longstanding threat to withdraw had been averted by a new plan to set up four regional research groups in Italy (see Nature 366, $604 ; 1993$ ).

The decision also throws EMBL's plans for the next few years into chaos. Italy contributes around 16 per cent of EMBL's annual budget of about DM10 million. Its withdrawal will therefore be a major blow at a time when the laboratory is expanding two of its three outstations, in Grenoble (France) and Cambridge (United Kingdom).

But laboratory officials still hope that Italy can be persuaded to change its mind. Italy first threatened to pull out of EMBL early last year, because it believed it was underrepresented among EMBL staff scientists. Its resignation letter indicates that it would be prepared to rejoin if the conditions were appropriate.

EMBL was founded in 1974 as a European focal point for molecular biology, and is currently paid for by subscriptions from 15 member states. It has always opposed a quota system for appointing staff scientists, arguing that appointments should be made on scientific merit alone.

The laboratory's new director, Fotis Kafatos, who was appointed last April, has suggested an alternative solution to complaints that this policy discriminates against member states that are less strong in molecular biology, namely that regional groups should be set up throughout southern European member states.

Under Kafatos's proposal, four of the five groups planned for a pilot scheme to start this year would be located in Italy, at a cost of about DM450,000 each. In a second phase of the pilot scheme, a further six would be established in Italy over the next four years, to be paid for out of funds raised

\section{Hubble shows off its new spectacles}

\section{IMAGE UNAVAILABLE FOR COPYRIGHT REASONS}

Astronomers and space scientists have been waiting with fingers crossed to see if the first images from the repaired Hubble Space Telescope were as good as predicted. Their wait has been rewarded. The picture on the right shows the nuclear region of NGC1068, an active Type 2 Seyfert galaxy, with unprecedented clarity. Previous observations (left) with the European Space Agency's Faint Object Camera (FOC) showed a number of hot gaseous clouds surrounding the intense nuclear source. New observations made by a team led by Duccio Maccheto of the European Space Agency and the Space Telescope Science Institute in Baltimore, Maryland, using the FOC with the corrective optics unit (COSTAR) installed by the astronauts, show a much more extensive area of emission.

The new picture also reveals filamentary detail in gas cloud near the nucleus in unprecedented detail. As the collective sigh of relief turns to jubilation, NASA is hoping for some respite from an increasingly critical public (see page 207).

\begin{tabular}{|c|c|c|c|c|c|c|c|c|c|}
\hline \multirow[b]{3}{*}{ Italy } & \multicolumn{2}{|c|}{$\begin{array}{c}\text { Staff } \\
\text { Scientists }\end{array}$} & \multirow{2}{*}{\multicolumn{2}{|c|}{$\begin{array}{c}\text { Staff } \\
\text { Technlcians } \\
\text { '89 ‘93 }\end{array}$}} & \multicolumn{2}{|c|}{ Fellows } & \multicolumn{2}{|c|}{$\begin{array}{l}\text { Visiting } \\
\text { Sclentists }\end{array}$} & \multirow[t]{2}{*}{$\begin{array}{l}\% \text { of } \\
\text { budget }\end{array}$} \\
\hline & ' 89 & ‘93 & & & '89 & 93 & 89 & 93 & \\
\hline & 9 & 4 & 4 & 3 & 24 & 21 & 5 & 7 & 16.2 \\
\hline Germany & 30 & 25 & 50 & 51 & 32 & 55 & 5 & 14 & 22.0 \\
\hline UK & 20 & 26 & 32 & 44 & 29 & 17 & 7 & 17 & 14.4 \\
\hline France & 9 & 9 & 16 & 21 & 18 & 26 & 3 & 8 & 17.0 \\
\hline
\end{tabular}

Losing out: Italy claims its scientists are underrepresented on EMBL's staff.

from outside bodies such as the European Commission.

The scheme was enthusiastically endorsed at EMBL's annual council meeting on 9 December. At the time, Italian officials seemed to regard it as an acceptable resolution of their grievances. There was therefore both surprise and disappointment when, less than three weeks later, Italy announced its withdrawal, saying it wanted to stimulate debate about the "national and international" reasons that have led to its low representation among the staff of EMBL facilities.

The number of Italian staff at EMBL has fallen considerably in the last few years, coinciding with an expansion of molecular biology in Italy, and the return of key scientists to take up new positions.

But the number of Italian staff scientists and technicians has always been low compared with those from Germany and the UK. Various reasons have been put forward to account for this, including the underdevelopment of molecular biology in Italy.

Arturo Falaschi, head of the International Centre of Genetic Engineering and Biotechnology in Trieste, who has been acting as an informal adviser to the Italian government, says that one factor in its decision was disappointment over what Italy sees as a lack of commitment by the council to the second phase of the pilot regional group programme.

Falaschi describes his government's action as "constructive", because it will ensure immediate discussion between EMBL members of its recruitment policy, a discussion in which Italy is keen to take part. "But we want to be in a better position to negotiate fairer returns," he says.

$\mathrm{He}$ adds that Italy is not demanding a full-blooded quota system, but merely some way of ensuring that EMBL employs more Italian scientists. He also suggests that greater consideration should be given to the creation of an outstation in Italy.

The decision has upset many of Italy's molecular biologists. Riccardo Cortesi, for example, who worked at EMBL for 11 years before moving to Rome in 1990 to run a major molecular biology laboratory, 
describes the withdrawal as an act of bad faith.

A petition signed by more than a hundred scientists has been sent to the minister of research, Umberto Colombo, and many individual protests have also been sent.

Kafatos says he intends to work hard over the next few months with Kari Kivirikko, the new president of the EMBL council, to try to resolve the dispute. "I deeply regret Italy's decision because I believe the association between Italy and EMBL is mutually beneficial, and also beneficial for science in Europe in general", says Kafatos, although he adds that the issues raised by Italy are "long-standing and need attention".

Plans for the regional groups are temporarily in abeyance. Kafatos says that the programme will go ahead, but exactly how, and where the groups will be located, are once again open for discussion.

Meanwhile senior scientists at EMBL's main laboratory in Heidelberg have been asked to look for potential savings in their research projects, in case Italy does not reverse its decision to resign.

The EMBL council meets next month to continue discussion of a proposal to raise contributions by two per cent in real terms to cover the costs of expanding its two outstations. No decision on this proposal was reached at last month's meeting, and the new meeting will also provide an opportunity to discuss Italy's resignation.

The outcome of this debate will be watched closely. The issues affect not only EMBL, but any joint scientific project in Europe, and Italy's action could set a precedent for other countries that feel that they do not get an adequate return for their investment in major international facilities.

Alison Abbott

\section{Mitterrand asked to pardon doctors in HIV blood scandal}

Paris. Ninety-seven researchers, physicians and public health workers this week sent a letter to President François Mitterrand asking him to pardon the four physicians convicted in July last year for their part in the contamination of French blood supplies with human immunodeficiency virus (HIV) in the mid-1980s (see Nature 364, 269; 1994).

The court handed down four-year prison terms to two former officials of the French National Centre for Blood Transfusion (CNTS), Michel Garretta and Jean-Pierre Allain, with two years of the sentence suspended. Robert Netter, former head of the National Health Laboratory, and Jacques Roux, former director-general of health at the National Ministry of Health, were given one- and three-year suspended sentences respectively.

In their letter to Mitterrand, the signatories - most of whom are from France, although some are from elsewhere describe the verdicts as "unfair". They say that the trial was prejudiced by intense media attention, and by the passions aroused by the affair among the general public.

Referring to the alleged scientific uncertainty worldwide about HIV in 1985 , the letter argues that the delay between scientific discoveries and their "validation, recognition and integration into general consciousness" is much longer than the public appreciates. "It is deeply unjust to punish a few selected individuals for the lacunae and dysfunctions of our health system as a whole," the letter adds.
The group says that its main concern is the possibility that those involved in making decisions "at the frontiers of scientific knowledge" could face similar verdicts in the future. The letter claims that fear of such "legal reprisals" could prevent physicians and researchers from "assuming their duty and from taking the responsibilities that are theirs", and thus hinder medical progress.

While confirming their "solidarity and compassion for the haemophiliacs and their families stricken by AIDS", the group says that it has a duty to guard against "any unjustified sentiment of mistrust against physicians and medical science, which would be counterproductive to medical health". It calls on Mitterrand to use his powers to prevent such a backlash, and asks him to grant a presidential pardon to the four convicted physicians.

The main signatories of the letter are Françoise Barré-Sinoussi of the Pasteur Institute, Paris, one of the co-discoverers of HIV, and Jean Claude Gluckmann of the Hôpital de la Pitié in Paris. Other signatories include William Blattner (National Cancer Institute, Bethesda, USA), Jean-Baptiste Brunet (European AIDS centre), Robin Carrell (Department of Haematology, Cambridge, UK), Jean Dausset (CEPH), Marc Giraud (Pasteur Institute, Paris), Willy Rozenbaum (Rothschild Hospital, Paris), Jorg Schupbach (Swiss National Centre for Retroviruses, Zurich) and Daniel Tarantola (International AIDS Program, Cambridge, USA).
Declan Butler

\section{Asian republics agree on joint rescue plan to save the Aral Sea}

London. Five central Asian republics, as well as Russia, formally agreed last week to set up a joint fund to save the inland Aral Sea, heavily depleted by the use of water for irrigating rice and cotton in surrounding regions.

Meeting in the Uzbek town of Nukus, the presidents of Uzbekistan, Kazakhstan, Kyrgyzstan, Turkmenistan, and Tajikistan, together with Russian Deputy Premier Yuriy Yarov, adopted an agreement to set up the fund, to which four of the five republics have agreed to provide one per cent of their annual state budgets.

The participants also agreed to take urgent steps to address the ecological problems of the area through the activities of an interstate council. The agreement on a conservation plan follows the decision by the World Bank in Washington and the United Nations Environment Programme to approve a grant to the five republics to carry out work on the prob- lems of the area.

First attempts to prevent the complete disappearance of the Aral Sea were made as a result of concerns expressed through the Academy of Sciences in the 1980s. However these efforts became victims of recent political upheavals in Moscow, leading to fears that the rescue mission might have to be aborted.

The shrinking of the sea, which was once the world's fourth-largest freshwater lake, has left many ships stranded in what is now little more than a sandy desert whose atmosphere is polluted with fertilizer toxins. This has itself caused widespread health problems in the local population.

Addressing a recent meeting organized by the World Health Organization in Alma-Ata, President Nazarbayev of

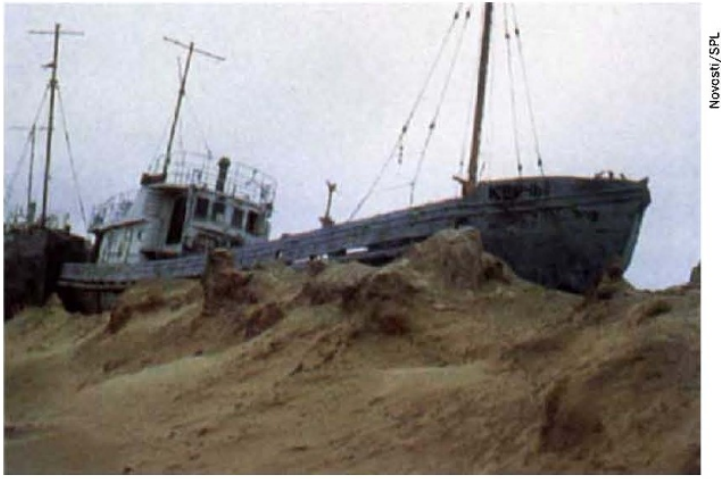

Sea of troubles: without help, the Aral Sea is in danger of running completely dry.

Kazakhstan said that he had been given promises by a number of heads of state and international agencies that they would support the new fund both technologically and financially. "Its aim is first of all to help people," Nazarbayev said. 